\title{
DNA Hypermethylation Status of Multiple Genes in Papillary Thyroid Carcinomas
}

\author{
Eiwa Ishida ${ }^{a}$ Mitsutoshi Nakamura $^{a}$ Keiji Shimada $^{a}$ Tomonori Higuchi ${ }^{a}$ \\ Keisuke Takatsu ${ }^{c}$ Katsunari Yane ${ }^{b}$ Noboru Konishi ${ }^{a}$ \\ Departments of a Pathology and ${ }^{\mathrm{b}}$ Otolaryngology, Nara Medical University School of Medicine, Nara, and \\ 'Department of Molecular Biology, Institute of Gerontology, Nippon Medical School, Kashihara, Japan
}

\section{Key Words}

Chronic inflammation - Homozygous deletion •

Methylation - Papillary thyroid carcinoma

\begin{abstract}
Objective: The aim of this study was hypermethylation of multiple genes for papillary thyroid carcinomas (PTCs). Methods: We examined 39 lesions using methylation-specific PCR to assess hypermethylation in genes, including $p 16^{I N K 4 a}, p 14^{A R F}, R B 1, p 27^{K i p 1}$ and $0^{6}-M G M T$. Homozygous deletions of $p 16^{I N K 4 a}$ and $p 14^{A R F}$ were investigated by differential $\mathrm{PCR}$, all with reference to clinicopathological factors. $\boldsymbol{R e}$ sults: We found methylation of p16 INK4a in $35.9 \%(14 / 39)$; $p 14^{A R F}$ in $2.6 \%(1 / 39) ; R B 1$ in $23.1 \%$ (9/39); $p 27^{K i p 1}$ in $15.4 \%$ (6/39), and $0^{6}-M G M T$ in $15.4 \%$ (6/39). Hypermethylation of at least one of these genes was apparent in $66.7 \%(26 / 39)$. Homozygous deletions of $p 14^{A R F}$ and $p 16^{I N K 4 a}$ were detected in $7.7(3 / 39)$ and $2.6 \%(1 / 39)$, respectively. In cases with p16 INK4a alterations, tumors were significantly increased. A history of chronic thyroid disease and lymphocytic infiltration was significantly associated with $p 14^{A R F}$ alterations, without regional lymph node metastases. Conclusions: Our data suggest that alterations in $p 16^{I N K 4 a}$, mainly hypermethylation, may be linked to tumor growth but not tumor development, while alterations in p14 ${ }^{A R F}$ may contribute to the induction of chronic inflammation-related PTCs.
\end{abstract}

Copyright $\odot 2007$ S. Karger AG, Basel
(ㄷ) 2007 S. Karger AG, Basel

1015-2008/07/0746-0344\$23.50/0

Fax +41613061234 E-Mail karger@karger.ch www.karger.com
Accessible online at:

www.karger.com/pat

\section{Introduction}

The papillary thyroid carcinoma (PTC) is the most frequent malignancy originating in the thyroid gland. With respect to gene alterations in carcinogenesis, PTCs have exceedingly low rates of loss of heterozygosity, with no specific region displaying a particularly high prevalence compared with follicular carcinomas [1], but somatic rearrangement of the sRET proto-oncogene has been detected in $25-35 \%$ of PTCs in the Western World $[2,3]$, and frequencies varied in Japanese cases $(3-36 \%)$ [4-6]. Recently, BRAF mutations, i.e. alternative molecular events, have been detected in $0-83 \%$ of PTCs, [7-10]. Finally, activated MAP kinase signaling caused by RET rearrangement, BRAF or RAS mutations, or other molecular alterations is thought to be essential for the induction of PTC [11]. However, the frequencies of gene alterations have been shown to differ in different ethnicities, reflecting different lifestyles, including nutrients such as iodine, and other mechanisms of PTC development and progression need to be identified.

The roles of DNA methylation in carcinogenesis have been highlighted for various types of cancers. Promotor hypermethylation of $\mathrm{CpG}$ islands has been shown to be an epigenetic change resulting in loss of function of responsive genes involved in cell cycle regulation and DNA repair. In PTCs, hypermethylation at exon 1 of $p 16^{I N K 4 a}$ was detected in $6(33.3 \%)$ of 20 primary tumors, indicat-

Dr. Eiwa Ishida

Department of Pathology, Nara Medical University School of Medicine 840 Shijo-cho

Kashihara, Nara 634-8521 (Japan)

Tel. +81 74422 3051, Fax +81 74423 5687, E-Mail eishida@naramed-u.ac.jp 
ing that the function of this gene may be lost during disease progression [12]. However, the knowledge on hypermethylation in PTCs is still insufficient.

In this study, a total of 39 tumors were evaluated using methylation-specific PCR (MSP) to assess hypermethylation in multiple genes implicated in regulatory processes, including $p 16^{I N K 4 a}, p 14^{A R F}, R B 1, p 27^{K i p 1}$ and $0^{6}-M G M T$. We also investigated homozygous deletions of $p 16^{I N K 4 a}$ and $p 14^{A R F}$, and protein expression by immunohistochemistry. The results showed statistically significant correlations between alterations in specific genes and certain clinicopathological features of the tumors.

\section{Materials and Methods}

Tumor Samples and DNA Extraction

Samples of 39 PTCs, consisting of conventional PTCs with well-differentiated histology, were obtained from the Department of Otolaryngology, Nara Medical University Hospital. Detailed clinicopathological data, e.g. age, sex, past history of chronic thyroid disease, tumor size, presence of regional lymph node metastasis, distant metastasis and clinical stage, were collected and summarized in table 1 . The patients comprised 9 males and 30 females, ranging in age from 12 to 79 years, with a mean of 54.1 years. Two had a past history of chronic thyroiditis, and 2 suffered from Graves' (Basedow's) disease. According to the TNM classification, 9 (23.1\%) presented with stage I, 12 (30.8\%) with stage II, 17 (43.6\%) with stage III and 1 (2.6\%) with stage IV lesions.

The tumor samples were all fixed in $10 \%$ buffered formalin and embedded in paraffin, cut at $4 \mu \mathrm{m}$ and stained with hematoxylin and eosin (HE) for histopathological evaluation, with especial focus on lymphocytic infiltration. DNA was extracted by methods described previously [13].

\section{Methylation-Specific PCR}

MSP is sufficiently sensitive to detect a single methylated allele among 1,000 unmethylated ones [14] and, therefore, may be the most appropriate methodology for identifying DNA methylation patterns within CpG islands of $p 16^{I N K 4 a}, p 14^{A R F}, R B 1, p 27^{K i p 1}$ and $0^{6}$-MGMT. MSP distinguishes unmethylated from methylated alleles based on sequence changes produced after bisulfite treatment of DNA, which converts only unmethylated cytosine to uracil, and subsequent PCR using primers designed for either methylated or unmethylated DNA. It was here performed using sodium bisulfite modification with a 'CpGenome' DNA modification kit (Intergen, Oxford, UK) according to the manufacturer's protocol with additional minor modification $[15,16]$. The primer sequences and the detailed MSP conditions have been reported previously $[14,17-22]$. The regions analyzed for $p 16^{I N K 4 a}, p 14^{A R F}$ and $0^{6}-M G M T$ were promoter regions of the transcriptional start site $[14,17,23]$. For $R B 1$ and $p 27^{K i p 1}$, the regions analyzed were promoter regions of the translational start site and exon 2, respectively $[20,22]$. Control methylated (Intergen) and unmethylated DNA from blood samples of normal volunteers were also treated with bisulfite as positive and negative controls. Amplified products were subsequently electrophoresed on $2 \%$ agarose gels and visualized by ethidium bromide staining.

DNA Hypermethylation in Papillary Thyroid Carcinomas
Differential PCR for $\mathrm{p} 14^{\mathrm{ARF}}$ and $\mathrm{p} 16^{\mathrm{INK} 4 \mathrm{a}}$ Deletions

To detect homozygous deletions, differential PCRs were carried out. Duplex PCR was performed to generate a 149-bp fragment covering exon $1 \beta$ of the $p 14^{A R F}$ gene, and a 204-bp exon fragment of $p 16^{I N K 4 a} 1 \alpha$, together with a 160 -bp fragment of the GAPDH gene and a 187-bp fragment of $\beta$-actin as internal controls, mainly to confirm the integrity of the template and also to assess contamination of samples by normal cells. Both sets of primers, for the control locus and the potentially deleted locus, were included in the PCR reaction mixture. DNA was amplified with 30 and 29 cycles of PCR for the $p 16^{I N K 4 a}$ and $p 14^{A R F}$ genes, respectively. The primer sequences and detailed PCR conditions have been described previously $[16,24]$. PCR products were analyzed on 8\% acrylamide gels and photographed using a DC290 Zoom Digital Camera (Eastman Kodak, Rochester, N.Y., USA). Densitometry was performed using Kodak Digital Science ID Image Analysis software (version 3.5.2; Eastman Kodak). Samples presenting $<20 \%$ of the control signal were considered homozygously deleted [16]. To assess the sensitivity of differential PCR for homozygous deletions, we performed a titration experiment with various ratios of normal DNA and DNA from A172 glioma cells with homozygous co-deletion of the $p 16^{I N K 4 a}$ and $p 14^{A R F}$ genes. The chosen threshold value of 0.2 allows the detection of homozygous deletions in the presence of approximately 30\% normal DNA for $p 16^{I N K 4 a}$ and $25 \%$ for $p 14^{A R F}[16]$.

\section{Immunohistochemistry}

Protein expression was assessed immunohistochemically, using a polyclonal antihuman p14 ${ }^{\mathrm{ARF}}$ antibody (FL-132: SC1661; Santa Cruz Biotechnology, Santa Cruz, Calif., USA) and monoclonal antibodies to p16 $6^{\text {INK4a }}$ (F-12: SC1661; Santa Cruz Biotechnology) and pRB (clone G3-245; PharMingen, San Diego, Calif., USA). Details on the conditions have been reported previously [25]. For p14 ${ }^{\mathrm{ARF}}, \mathrm{p} 16^{\mathrm{INK} 4 \mathrm{a}}$ and $\mathrm{pRB}$ immunostaining, reactivity was recorded as negative when $<5 \%$ of cancer cells demonstrated staining, in agreement with a previous study [21].

\section{Statistical Methods}

Statistical analyses were performed using StatView-J 5.0 to analyze correlations between clinicopathological factors and genetic alterations. Tumor size and stage were divided into two groups, T1/2 and T3/4, and SI/II and SIII/IV, respectively. Associations between tumor variables were assessed by Fisher's exact test. Significance was defined as $\mathrm{p}<0.05$.

\section{Results}

\section{Gene Methylation in PTC}

Table 1 summarizes the methylation status for the five genes analyzed in this study. We found methylation of p16 ${ }^{I N K 4 a}$ in $35.9 \%(14 / 39) ; p 14^{A R F}$ in $2.6 \%(1 / 39) ; R B 1$ in $23.1 \%$ (9/39); $p 27^{K i p 1}$ in $15.4 \%$ (6/39), and $0^{6}-M G M T$ in $15.4 \%(6 / 39)$. Representative methylation patterns are illustrated in figure 1 . Hypermethylation of at least one of the genes was detected in $66.7 \%(26 / 39)$ of the samples. Methylated and unmethylated DNAs showed the expect- 
Table 1. Clinicopathological factors and genetic and epigenetic alterations in the 39 PTCs

\begin{tabular}{|c|c|c|c|c|c|c|c|c|c|c|c|c|c|c|}
\hline $\begin{array}{l}\text { Case } \\
\text { No. }\end{array}$ & $\begin{array}{l}\text { Age } \\
\text { years }\end{array}$ & Sex & CTD & Tumor & Node & $\begin{array}{l}\text { Metas- } \\
\text { tases }\end{array}$ & EX & Stage & LI & $p 14^{A R F}$ & $p 16^{I N K 4 a}$ & $R B 1$ & $p 27^{\text {Kip1 }}$ & $O^{6}-M G M T$ \\
\hline 1 & 29 & $\mathrm{~F}$ & - & $\mathrm{T} 2$ & - & - & - & I & - & - & - & - & - & - \\
\hline 2 & 12 & $\mathrm{~F}$ & - & $\mathrm{T} 3$ & + & - & - & I & - & - & M & - & - & - \\
\hline 3 & 71 & $\mathrm{M}$ & $\mathrm{U}$ & $\mathrm{T} 4$ & + & - & + & III & - & - & M & - & - & - \\
\hline 4 & 79 & $\mathrm{~F}$ & - & $\mathrm{T} 2$ & + & - & + & III & - & - & - & - & - & - \\
\hline 5 & 38 & $\mathrm{~F}$ & - & $\mathrm{T} 2$ & + & - & - & I & - & - & M & - & $\mathrm{M}$ & - \\
\hline 6 & 46 & $\mathrm{M}$ & - & $\mathrm{T} 3$ & - & - & - & II & - & - & M & $\mathrm{M}$ & - & M \\
\hline 7 & 30 & $\mathrm{~F}$ & - & $\mathrm{T} 2$ & + & - & + & I & + & - & M & $\mathrm{M}$ & - & - \\
\hline 8 & 69 & $\mathrm{~F}$ & - & $\mathrm{T} 2$ & + & - & + & III & - & - & - & - & - & - \\
\hline 9 & 78 & $\mathrm{M}$ & - & $\mathrm{T} 4$ & + & + & - & IV & - & - & M & - & - & - \\
\hline 10 & 79 & $\mathrm{~F}$ & - & $\mathrm{U}$ & + & - & $\mathrm{U}$ & III & - & - & $\mathrm{D}$ & - & $\mathrm{M}$ & - \\
\hline 11 & 56 & $\mathrm{~F}$ & - & $\mathrm{T} 2$ & + & - & + & III & + & - & $\mathrm{M}$ & - & - & - \\
\hline 12 & 66 & $\mathrm{~F}$ & - & $\mathrm{T} 2$ & + & - & + & III & - & - & - & - & - & $\mathrm{M}$ \\
\hline 13 & 68 & $\mathrm{~F}$ & - & $\mathrm{T} 2$ & + & - & + & III & - & - & - & - & - & - \\
\hline 14 & 48 & $\mathrm{~F}$ & - & $\mathrm{T} 2$ & + & - & - & III & - & - & - & $\mathrm{M}$ & - & - \\
\hline 15 & 64 & $\mathrm{~F}$ & - & $\mathrm{T} 2$ & - & - & - & II & - & - & - & - & $\mathrm{M}$ & - \\
\hline 16 & 51 & $\mathrm{M}$ & - & T3 & + & - & - & III & - & - & - & - & - & - \\
\hline 17 & 66 & $\mathrm{M}$ & - & $\mathrm{T} 2$ & + & - & - & III & - & - & - & $\mathrm{M}$ & - & - \\
\hline 18 & 77 & $\mathrm{~F}$ & - & $\mathrm{T} 2$ & + & - & + & III & - & - & - & - & $\mathrm{M}$ & - \\
\hline 19 & 63 & $\mathrm{~F}$ & - & $\mathrm{T} 3$ & + & - & + & III & - & - & $\mathrm{M}$ & - & - & - \\
\hline 21 & 49 & $\mathrm{~F}$ & - & $\mathrm{T} 2$ & - & - & - & II & + & - & - & - & - & - \\
\hline 22 & 50 & $\mathrm{~F}$ & - & $\mathrm{T} 2$ & + & - & - & III & - & - & - & - & - & - \\
\hline 24 & 56 & $\mathrm{~F}$ & - & $\mathrm{T} 2$ & + & - & - & III & - & - & - & - & - & - \\
\hline 25 & 30 & $\mathrm{~F}$ & GD & $\mathrm{T} 1$ & - & - & - & I & + & - & - & - & - & - \\
\hline 26 & 73 & $\mathrm{~F}$ & - & $\mathrm{U}$ & + & - & $\mathrm{U}$ & III & - & - & - & - & - & $\mathrm{M}$ \\
\hline 28 & 66 & $\mathrm{~F}$ & - & $\mathrm{T} 2$ & + & - & - & III & - & - & - & $\mathrm{M}$ & $\mathrm{M}$ & - \\
\hline 29 & 29 & $\mathrm{~F}$ & - & $\mathrm{T} 2$ & + & - & - & I & - & - & - & $\mathrm{M}$ & - & - \\
\hline 30 & 32 & $\mathrm{M}$ & - & $\mathrm{T} 1$ & + & - & - & I & - & $\mathrm{D}$ & - & - & - & $\mathrm{M}$ \\
\hline 31 & 44 & $\mathrm{M}$ & - & $\mathrm{T} 2$ & + & - & - & I & - & - & - & $\mathrm{M}$ & - & - \\
\hline 33 & 64 & $\mathrm{~F}$ & CT & $\mathrm{T} 2$ & - & - & - & II & + & $\mathrm{M}$ & $\mathrm{M}$ & - & - & $\mathrm{M}$ \\
\hline 34 & 58 & $\mathrm{~F}$ & - & $\mathrm{T} 4$ & + & - & + & III & - & - & $\mathrm{M}$ & - & - & - \\
\hline 38 & 46 & $\mathrm{M}$ & - & $\mathrm{T} 3$ & - & - & - & II & - & $\mathrm{D}$ & $\mathrm{M}$ & - & - & - \\
\hline 41 & 18 & $\mathrm{~F}$ & - & $\mathrm{T} 2$ & + & - & - & I & - & - & $\mathrm{M}$ & $\mathrm{M}$ & - & - \\
\hline 42 & 49 & $\mathrm{~F}$ & - & $\mathrm{T} 2$ & - & - & - & II & + & - & - & - & - & - \\
\hline 44 & 75 & $\mathrm{~F}$ & GD & $\mathrm{T} 2$ & - & - & - & II & + & $\mathrm{D}$ & - & - & - & - \\
\hline 46 & 45 & $\mathrm{~F}$ & - & $\mathrm{T} 2$ & - & - & - & II & - & - & $\mathrm{M}$ & - & - & - \\
\hline 48 & 60 & $\mathrm{M}$ & - & $\mathrm{T} 3$ & - & - & - & II & - & - & $\mathrm{M}$ & $\mathrm{M}$ & - & - \\
\hline 53 & 65 & $\mathrm{~F}$ & - & T3 & - & - & - & II & - & - & - & - & - & - \\
\hline 54 & 58 & $\mathrm{~F}$ & CT & $\mathrm{T} 2$ & - & - & - & II & + & - & - & - & $\mathrm{M}$ & $\mathrm{M}$ \\
\hline 55 & 51 & $\mathrm{~F}$ & - & $\mathrm{T} 2$ & - & - & - & II & - & - & - & - & - & - \\
\hline
\end{tabular}

$\mathrm{CTD}=$ Chronic thyroid disease GD = Graves' disease; $\mathrm{CT}=$ chronic thyroiditis; EX = extension beyond the glands; LI = lymphocytic infiltration; $\mathrm{M}$ = methylated; $\mathrm{D}=$ deletion; $\mathrm{U}=$ unknown.

ed fragment sizes of 150 and 151 bp for $p 16^{I N K 4 a} ; 122$ and $132 \mathrm{bp}$ for $p 14^{A R F} ; 81$ and $93 \mathrm{bp}$ for $0^{6}-M G M T ; 163$ and 163 bp for $R B 1$, and 195 and $212 \mathrm{bp}$ for $p 27^{K i p 1}$, respectively.

\section{p14 ${ }^{\mathrm{ARF}}$ and $\mathrm{p} 16^{\mathrm{INK} 4 \mathrm{a}}$ Deletions}

As shown in table 1, homozygous deletions in $p 14^{A R F}$ and $p 16^{I N K 4 a}$ were detected in $3(7.7 \%)$ and $1(2.6 \%)$ of the
39 samples, respectively. Representative deletion patterns are illustrated in figure 2 .

\section{Immunohistochemistry}

Nuclear immunoreactivity for $\mathrm{p} 14^{\mathrm{ARF}}, \mathrm{p} 16^{\mathrm{INK} 4 \mathrm{a}}$ and pRB was significantly correlated with a lack of hypermethylation or homozygous deletion (fig. 3). 
Fig. 1. Methylation-specific PCR for $\mathrm{CpG}$ islands in $p 16^{I N K 4 a}, p 14^{A R F}, R B 1, p 27^{K i p 1}$ and $0^{6}-M G M T$ genes in PTCs. A 25-bp DNA ladder (Invitrogen, Carlsbad, Calif., USA) is shown on the left as a molecular weight marker. The presence of a visible PCR product in lane $\mathrm{U}$ indicates an unmethylated gene: the presence of a product in lane $\mathrm{M}$ indicates a methylated gene. Case numbers are indicated above each gel. Cases 2, 3 and 5 for $p 16^{I N K 4 a}$, case 33 for $p 14^{A R F}$, cases 6,7 and 14 for $R B 1$, cases 5 and 10 for $p 27^{K i p 1}$, and cases 6 and 12 for $0^{6}-M G M T$ are methylated. NC $=$ Negative control DNA from normal blood sample; $\mathrm{PC}=$ positive control for methylated DNA.

Fig. 2. Differential PCR for assessment of p14 ${ }^{A R F}$ and $p 16^{I N K 4 a}$ homozygous deletions in PTCs. Cases 30, 38 and 44 have $p 14^{A R F}$ homozygous deletions, and case 10 has a p16 ${ }^{I N K 4 a}$ homozygous deletion. Cases 8, 9 and 46 have a normal gene status. $\mathrm{NC}=$ Negative control DNA from a normal blood sample.

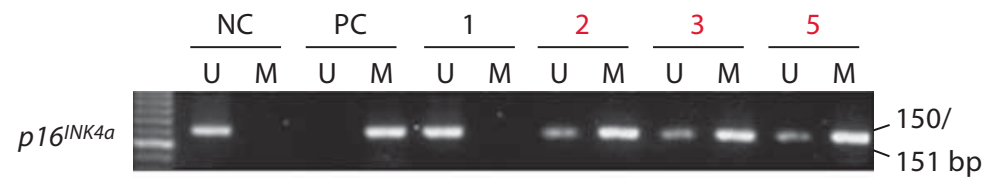

$\frac{N C}{U M} \frac{P C}{U M} \frac{1}{U M} \frac{2}{U M} \frac{3}{U M} \frac{33}{U M}$

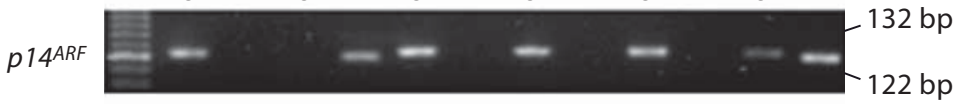

$\frac{N C}{U M} \frac{P C}{U M} \frac{6}{U M} \frac{7}{U M} \frac{14}{U M} \frac{17}{U M} \frac{18}{U M}$

$R B 1$

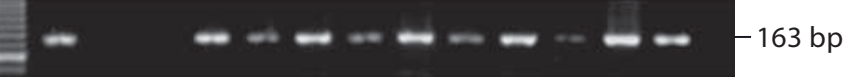

$\frac{N C}{U M} \frac{P C}{U M} \frac{6}{U M} \frac{7}{U M} \frac{14}{U M} \frac{17}{U M} \frac{18}{U M}$

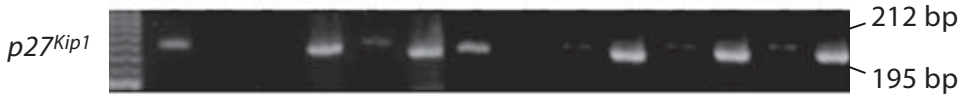

$$
\frac{N C}{U M} \frac{P C}{U M} \frac{1}{U M} \frac{6}{U M} \frac{12}{U M}
$$

$0^{6-M G M T}$

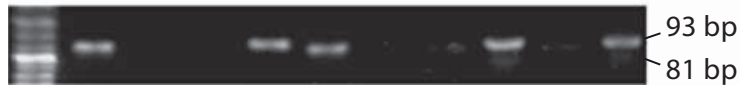

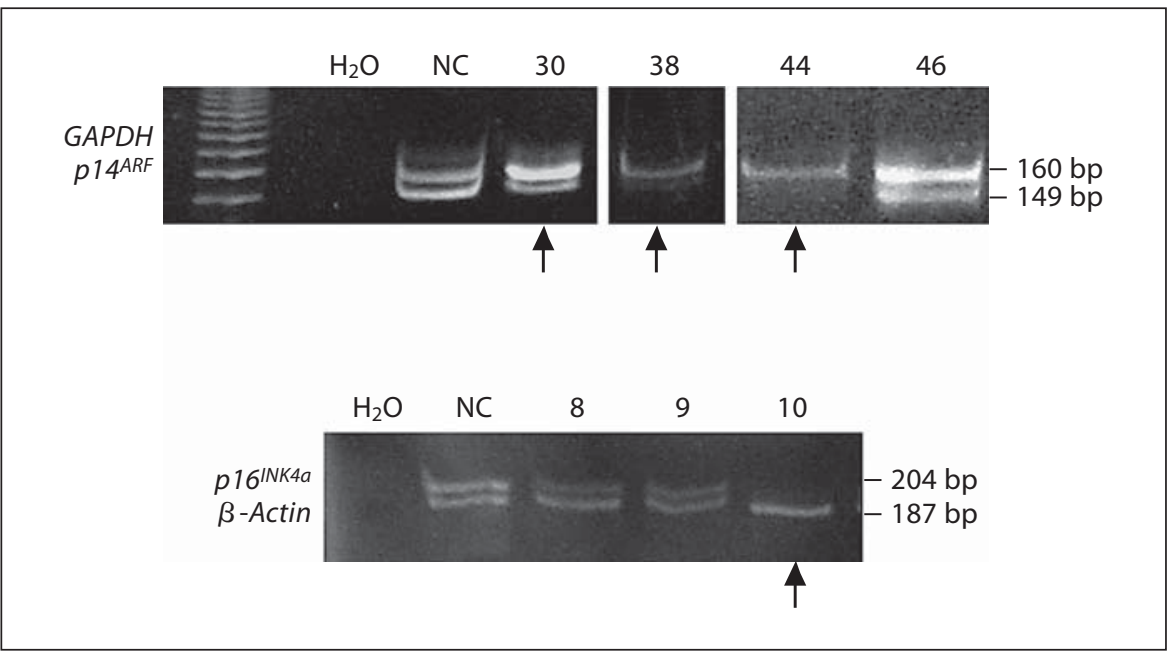

\section{Clinicopathological Factors and Gene Alterations}

We examined each tumor sample for potential causal relationships by comparing genetic and epigenetic alterations with clinicopathological parameters. As shown in table 2, tumors with $p 16^{I N K 4 a}$ alterations, mainly hyper- methylation, were significantly larger $(p=0.0023)$. In cases with a previous history of chronic thyroid disease, lymphocytic infiltration was a significant finding $(\mathrm{p}=0.0009)$, together with $p 14^{A R F}$ alterations $(\mathrm{p}=0.0475)$ and infrequent metastases to regional lymph nodes $(\mathrm{p}=0.0136)$. 

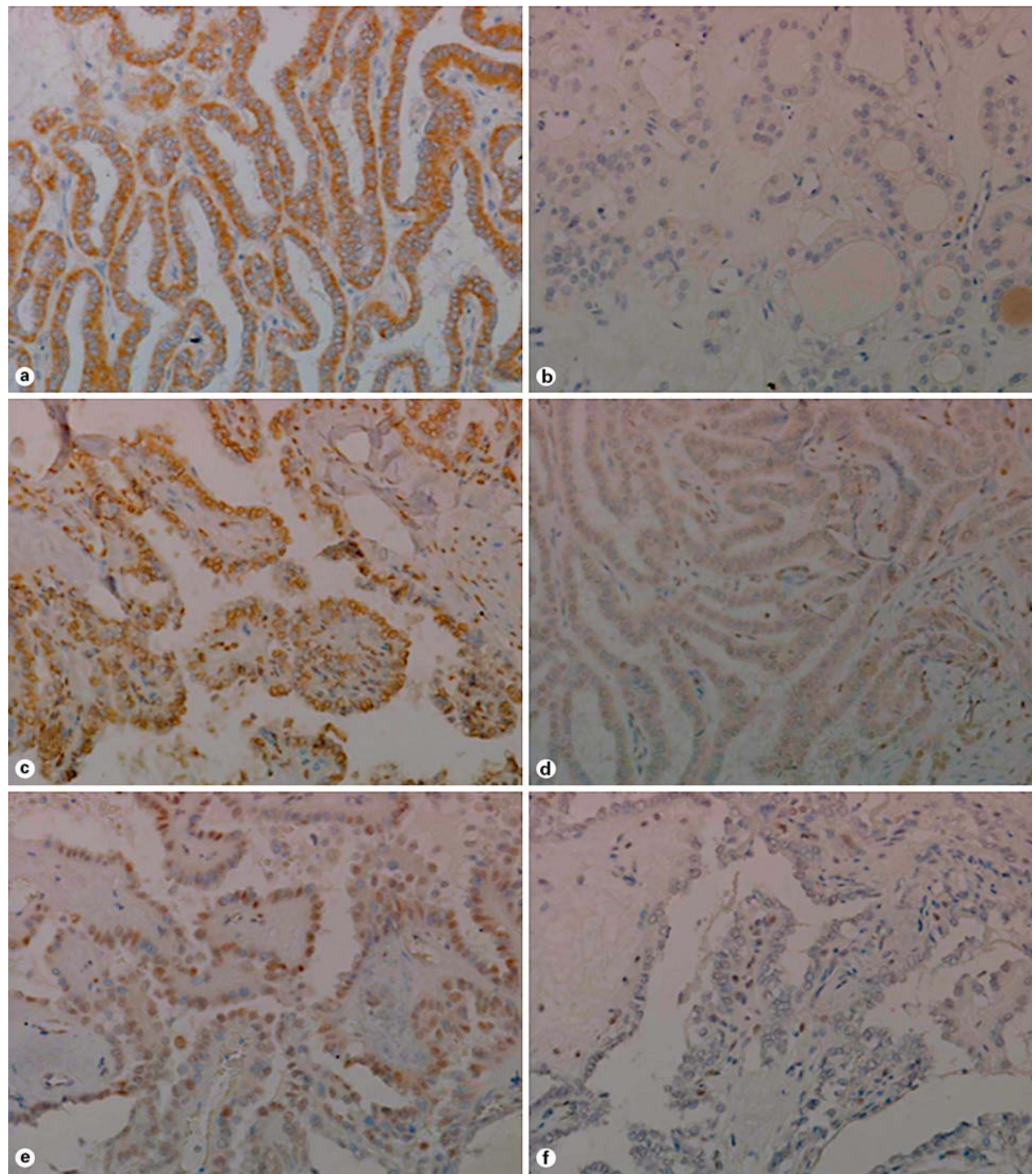

Fig. 3. With $\mathrm{p} 14^{\mathrm{ARF}}$ immunohistochemistry, case 2 without $p 14^{A R F}$ alteration shows positive staining (a), and case 44 with p14 ${ }^{A R F}$ deletion is negative (b). With p16 ${ }^{I N K 4 a}$ immunohistochemistry, case 1 without $p 16^{I N K 4 a}$ alteration is positive (c), and case 2 with $p 16^{I N K 4 a}$ methylation is negative (d). With pRB immunohistochemistry, case 5 without $R B 1$ methylation demonstrates focally positive staining (e), and case 41 with $R B 1$ methylation is negative (f). 
Table 2. Correlations between clinicopathological factors and gene alterations in PTCs

\begin{tabular}{|c|c|c|c|c|c|c|c|c|}
\hline Factors & $p 14^{A R F}$ & $p 16^{I N K 4 a}$ & $R B 1$ & $\begin{array}{l}\text { Overall } \\
\text { status for } \\
\text { alteration }\end{array}$ & $\begin{array}{l}\text { Tumor } \\
(\mathrm{T} 1 / 2)\end{array}$ & Node & Metastases & LI \\
\hline \multicolumn{9}{|l|}{ Tumor } \\
\hline $\mathrm{T} 1 / 2$ & $3 / 27$ & $6 / 27$ & $7 / 27$ & $17 / 27$ & - & $17 / 27$ & $0 / 27$ & - \\
\hline $\mathrm{T} 3 / 4$ & $1 / 10$ & $8 / 10$ & $2 / 10$ & $8 / 10$ & - & $6 / 10$ & $1 / 10$ & - \\
\hline $\mathrm{p}$ value & $>0.999$ & 0.0023 & $>0.999$ & 0.445 & - & $>0.999$ & 0.270 & - \\
\hline \multicolumn{9}{|l|}{ Node } \\
\hline+ & $1 / 25$ & $10 / 25$ & $7 / 25$ & $19 / 25$ & - & - & $1 / 25$ & - \\
\hline- & $3 / 14$ & $5 / 14$ & $2 / 14$ & $8 / 14$ & - & - & $0 / 14$ & - \\
\hline $\mathrm{p}$ value & 0.123 & $>0.999$ & 0.445 & 0.287 & - & - & $>0.999$ & - \\
\hline \multicolumn{9}{|c|}{ Metastases } \\
\hline+ & $0 / 1$ & $1 / 1$ & $0 / 1$ & $1 / 1$ & - & - & - & - \\
\hline- & $4 / 38$ & $14 / 38$ & $9 / 38$ & $26 / 38$ & - & - & - & - \\
\hline $\mathrm{p}$ value & $>0.999$ & 0.385 & $>0.999$ & $>0.999$ & - & - & - & - \\
\hline \multicolumn{9}{|l|}{$L I$} \\
\hline+ & $2 / 8$ & $3 / 8$ & $1 / 8$ & $5 / 8$ & $8 / 8$ & $2 / 8$ & $0 / 8$ & - \\
\hline- & $2 / 31$ & $12 / 31$ & $8 / 31$ & $22 / 31$ & $19 / 31$ & $23 / 31$ & $1 / 31$ & - \\
\hline $\mathrm{p}$ value & 0.180 & $>0.999$ & 0.653 & 0.683 & 0.079 & 0.0161 & $>0.999$ & - \\
\hline \multicolumn{9}{|l|}{$C T D$} \\
\hline+ & $2 / 4$ & $1 / 4$ & $0 / 4$ & & $4 / 4$ & $0 / 4$ & $0 / 4$ & $4 / 4$ \\
\hline- & $2 / 34$ & $13 / 34$ & $9 / 34$ & $23 / 34$ & $23 / 34$ & $24 / 34$ & $1 / 34$ & $4 / 34$ \\
\hline $\mathrm{p}$ value & 0.0475 & $>0.999$ & 0.555 & $>0.999$ & 0.553 & 0.014 & $>0.999$ & 0.0009 \\
\hline \multicolumn{9}{|l|}{ Sex } \\
\hline Males & $2 / 9$ & $5 / 9$ & $4 / 9$ & $8 / 9$ & $3 / 9$ & $6 / 9$ & $1 / 9$ & $0 / 9$ \\
\hline Females & $2 / 30$ & $10 / 30$ & $5 / 30$ & $19 / 30$ & $24 / 30$ & $19 / 30$ & $0 / 30$ & $8 / 30$ \\
\hline $\mathrm{p}$ value & 0.223 & 0.266 & 0.170 & 0.228 & 0.0053 & $>0.999$ & 0.231 & 0.160 \\
\hline
\end{tabular}

LI = Lymphocytic infiltration; CTD = chronic thyroid disease. Significant $\mathrm{p}$ values are shown in bold.

\section{Discussion}

Activated MAP kinase signaling caused by RET rearrangement, $\mathrm{BRAF}$ or RAS mutations, or other molecular alterations, is thought to be essential for the genesis of PTC [11]. However, the frequencies of the above-described gene alterations vary according to ethnicity. For example, rearrangements of the RET proto-oncogene in PTCs are relatively frequent $[2,3]$, although prevalence varies considerably (3-36\%) in Japan [4-6], and other mechanisms of tumor development and PTC progression need to be clarified. The role of DNA hypermethylation in tumor suppressor or DNA repair genes in carcinogenesis has been highlighted. Therefore, we aimed to examine the methylation status of five implicated genes and homozygous deletions of $p 14^{A R F}$ and $p 16^{I N K 4 a}$ and to correlate them with clinicopathological factors.

DNA Hypermethylation in Papillary

Thyroid Carcinomas
Cell proliferation is regulated by a family of CDKs, and $16^{\text {INK4a }}$ is a CDKI which specifically inhibits CDK4/6 and consequently cyclin $\mathrm{D}$-dependent phosphorylation of $\mathrm{Rb}$, leading to less transcription of E2F-responsive genes necessary for S-phase entry [26]. Deregulation of the $p 16^{I N K 4 a}$ gene product through loss of heterozygosity, promoter hypermethylation and/or mutations in the INK4a/ARF locus is a common phenomenon in the transformation process, which is often found in more aggressive tumors [27]. In this study, the frequency of $p 16^{I N K 4 a}$ hypermethylation of PTC was found to be $38.5 \%$, in line with a previous study [12]. Interestingly, in the 15 cases with $p 16^{I N K 4 a}$ alterations, consisting of 14 with hypermethylation and only 1 with homozygous deletions, tumors were significantly larger (T3 and T4), suggesting that $p 16^{I N K 4 a}$ alterations in PTCs are associated with tumor growth or progression, but not tumor development. There was no association between $p 16^{I N K 4 a}$ alterations

Pathobiology 2007;74:344-352 
and clinical stage in this study. For the TNM classification of PTC, age is thought to be an important factor; patients below 45 years of age without distant metastases are grouped in stage I, irrespective of the tumor size and the presence of lymph node metastases.

pRB ( $R B 1$ gene products) is a negative regulator of cell proliferation, and in a hypophosphorylated state, $\mathrm{pRb}$ exerts its antiproliferative function by sequestering and altering the function of the E2F family of transcription factors that control the expression of a bank of genes essential for cells to progress from G1 to the S phase [27]. The importance of $R B 1$ in cancer development is well established, and most human cancers show somatic alterations, either in $\mathrm{pRB}$ or other components of the pathway [28]. To our knowledge, we were the first to report $R B 1$ hypermethylation in PTCs, and a relatively high frequency was detected (23.1\%), though previous immunohistochemical studies of RB expression in PTCs gave conflicting results $[29,30]$. In our previous study, a clear correlation between $R B 1$ alterations and immunohistochemical expression was noted [15]. The present findings suggest that the $R B 1$ gene might play a role in thyroid tumorigenesis, although no significant association between $R B 1$ gene methylations and clinicopathological factors was revealed. An inverse correlation between $p 16^{I N K 4 a}$ and $R B 1$ expression was found, demonstrating that each of the alterations can lead to cancer formation [31]. With respect to the association between $p 16^{I N K 4 a}$ alterations and cancer growth, further studies including other mechanisms of $\mathrm{pRB}$ loss are required to establish the hypothesis that alterations in the $p 16^{I N K 4 a} / R B 1$ pathway induce cancer growth in PTCs.

$p 14^{A R F}$ plays a major role in the $p 53$ pathway by binding specifically to MDM2, resulting in stabilization of both p53 and MDM2 [32].p27 ${ }^{\text {Kip1 }}$ encodes a cyclin kinase inhibitor, which acts as a potent tumor suppressor gene in a variety of human cancers [33]. $O^{6}-M G M T$ encodes a DNA repair protein, and prevents mutations and cell death that result from aberrant alkylation of DNA [34]. With regard to hypermethylation of $p 14^{A R F}, p 27^{K i p 1}$ and $O^{6}-M G M T$ in PTCs, the frequencies found here were low (2.6, 15.4 and $15.5 \%$, respectively), and there was no link with clinicopathological factors, indicating that inactivation of these genes is not a major incidence in PTC tumorigenesis. Thyroid neoplasms, including PTCs, exhibit significantly decreased $\mathrm{p} 27^{\mathrm{Kip} 1}$ expression [35], especially in nonmetastasizing PTCs [36], but this is presumably due to other mechanisms.

Our cases with a previous history of chronic thyroid disease demonstrated significant lymphocytic infiltra- tion in otherwise normal parenchyma adjacent to the cancers. Of particular interest, there was a significant association between chronic thyroid disease and $p 14^{A R F}$ alterations or lack of regional lymph node metastasis. Two of the 4 cases with $p 14^{A R F}$ alterations had a past history of chronic thyroid disease. In general, gastric cancers exhibit a high level of aberrant $\mathrm{CpG}$ island methylation, and gastritis with marked infiltration of mononuclear cells also displays a number of alterations in genes like $p 14^{A R F}$, suggesting that chronic inflammation may be closely associated with increased methylation in nonneoplastic gastric mucosa [37]. Similarly, higher frequencies of p14 ${ }^{A R F}$ hypermethylation have been reported in ulcerative colitis-associated colorectal carcinomas and nonneoplastic ulcerative colitis mucosa than in normal colonic mucosa [38]. Although our study included only a small number of cases with chronic thyroid disease, $p 14^{A R F}$ alterations are involved in chronic inflammationrelated PTCs. An association between lymphocyte infiltration and tumor progression has also been reported [39-41], and lymphocytes may help to interrupt tumor growth immunologically in the absence of regionallymph node metastasis.

Additionally, immunohistochemically 14 cases (35.9\%) expressed RET, showing clear nuclear and cytoplasmic staining, in contrast to a previous study [42], with no significant association with changes at the gene level and clinicopathological factors (data not shown). Polyclonal antibody against RET recognizes both rearranged and mutated RET oncogene proteins, and a previous report demonstrated a significant correlation between immunohistochemical RET overexpression and RET rearrangement, which was confirmed by RT-PCR [43]. A recent report showed that positive staining does not necessarily mean the presence of a rearrangement [44], and associations between RET rearrangement and clinicopathological factors or gene alterations require further evaluation.

Recent reports have indicated that $B R A F$ mutations can be detected in $0-80 \%$ of PTCs, as alternative events to RET rearrangement [7-10]. Others have reported early RASSF1A hypermethylation and mutual exclusion with $B R A F$ mutations in PTCs, and it is conceivable that $B R A F$ or Ras mutations, RET rearrangements and RASSF1A hypermethylation could complete the panel of genetic and epigenetic alterations responsible for PTC generation [45]. Our results indicate that of the $p 16^{I N K 4 a}$ alterations, mainly hypermethylation may be associated with tumor progression, and regarding chronic inflammation-related PTCs, $p 14^{A R F}$ alteration may be a key issue. 


\section{References}

-1 Ward LS, Brenta G, Medvedovic M, Fagin JA: Studies of allelic loss in thyroid tumors reveal major differences in chromosomal instability between papillary and follicular carcinomas. J Clin Endocrinol Metab 1998; 83:525-530

-2 Grieco M, Santoro M, Berlingieri MT, Melillo RM, Donghi R, Bongarzone I, Pierotti MA, Della Porta G, Fusco A, Vecchio G: PTC is a novel rearranged form of the ret protooncogene and is frequently detected in vivo in human thyroid papillary carcinomas. Cell 1990;60:557-563.

$\checkmark 3$ Bongarzone I, Butti MG, Coronelli S, Borrello MG, Santoro M, Mondellini P, Pilotti S, Fusco A, Della Porta G, Pierotti MA: Frequent activation of ret protooncogene by fusion with a new activating gene in papillary thyroid carcinomas. Cancer Res 1994;54: 2979-2985

4 Wajjwalku W, Nakamura S, Hasegawa Y, Miyazaki K, Satoh Y, Funahashi H, Matsuyama M, Takahashi M: Low frequency of rearrangements of the ret and trk proto-oncogenes in Japanese thyroid papillary carcinomas. Jpn J Cancer Res 1992;83:671-675.

$\checkmark 5$ Motomura T, Nikiforov YE, Namba H, Ashizawa K, Nagataki S, Yamashita S, Fagin JA: Ret rearrangements in Japanese pediatric and adult papillary thyroid cancers. Thyroid 1998;8:485-489.

6 Kitamura Y, Minobe K, Nakata T, Shimizu K, Tanaka S, Fujimori M, Yokoyama S, Ito K, Onda M, Emi M: Ret/ptc3 is the most frequent form of gene rearrangement in papillary thyroid carcinomas in Japan. J Hum Genet 1999;44:96-102.

-7 Kimura ET, Nikiforova MN, Zhu Z, Knauf JA, Nikiforov YE, Fagin JA: High prevalence of braf mutations in thyroid cancer: genetic evidence for constitutive activation of the ret/ptc-ras-braf signaling pathway in papillary thyroid carcinoma. Cancer Res 2003;63: 1454-1457.

$\checkmark 8$ Soares P, Trovisco V, Rocha AS, Lima J, Castro P, Preto A, Maximo V, Botelho T, Seruca $\mathrm{R}$, Sobrinho-Simoes M: BRAF mutations and RET/PTC rearrangements are alternative events in the etiopathogenesis of PTC. Oncogene 2003;22:4578-4580.

9 Xing M: BRAF mutation in thyroid cancer. Endocr Relat Cancer 2005;12:245-262.

- 10 Takahashi K, Eguchi H, Arihiro K, Ito R, Koyama K, Soda M, Cologne J, Hayashi Y, Nakata Y, Nakachi K, Hamatani K: The presence of BRAF point mutation in adult papillary thyroid carcinomas from atomic bomb survivors correlates with radiation dose. Mol Carcinog 2007;46:242-248.

$\checkmark 11$ Wojciechowska K, Lewinski A: BRAF mutations in papillary thyroid carcinoma. Endocr Regul 2006;40:129-138.
12 Elisei R, Shiohara M, Koeffler HP, Fagin JA: Genetic and epigenetic alterations of the cyclin-dependent kinase inhibitors p15ink4b and p16ink4a in human thyroid carcinoma cell lines and primary thyroid carcinomas. Cancer 1998;83:2185-2193.

13 Konishi N, Hiasa Y, Matsuda H, Tao M, Tsuzuki T, Hayashi I, Kitahori Y, Shiraishi T, Yatani R, Shimazaki J, et al: Intratumor cellular heterogeneity and alterations in ras oncogene and p53 tumor suppressor gene in human prostate carcinoma. Am J Pathol 1995; 147:1112-1122.

14 Herman JG, Graff JR, Myohanen S, Nelkin BD, Baylin SB: Methylation-specific PCR: a novel PCR assay for methylation status of CpG islands. Proc Natl Acad Sci USA 1996; 93:9821-9826.

15 Nakamura M, Yonekawa Y, Kleihues P, Ohgaki $\mathrm{H}$ : Promoter hypermethylation of the RB1 gene in glioblastomas. Lab Invest 2001; 81:77-82.

16 Nakamura M, Watanabe T, Klangby U, Asker C, Wiman K, Yonekawa Y, Kleihues P, Ohgaki H: p14ARF deletion and methylation in genetic pathways to glioblastomas. Brain Pathol 2001;11:159-168.

17 Esteller M, Hamilton SR, Burger PC, Baylin SB, Herman JG: Inactivation of the DNA repair gene O6-methylguanine-DNA methyltransferase by promoter hypermethylation is a common event in primary human neoplasia. Cancer Res 1999;59:793-797.

18 Esteller M, Sanchez-Cespedes M, Rosell R, Sidransky D, Baylin SB, Herman JG: Detection of aberrant promoter hypermethylation of tumor suppressor genes in serum DNA from non-small cell lung cancer patients. Cancer Res 1999;59:67-70.

19 Esteller M, Toyota M, Sanchez-Cespedes M, Capella G, Peinado MA, Watkins DN, Issa JP, Sidransky D, Baylin SB, Herman JG: Inactivation of the DNA repair gene O6-methylguanine-DNA methyltransferase by promoter hypermethylation is associated with $\mathrm{G}$ to A mutations in K-ras in colorectal tumorigenesis. Cancer Res 2000;60:2368-2371.

20 Simpson DJ, Hibberts NA, McNicol AM, Clayton RN, Farrell WE: Loss of pRB expression in pituitary adenomas is associated with methylation of the RB1 CpG island. Cancer Res 2000;60:1211-1216.

21 Nakamura M, Sakaki T, Hashimoto H, Nakase H, Ishida E, Shimada K, Konishi N: Frequent alterations of the $p 14^{\text {arf }}$ and $p 16^{\text {ink } 4 a}$ genes in primary central nervous system lymphomas. Cancer Res 2001;61:63356339

22 Konishi N, Nakamura M, Kishi M, Nishimine M, Ishida E, Shimada K: DNA hypermethylation status of multiple genes in prostate adenocarcinomas. Jpn J Cancer Res 2002;93:767-773.
23 Esteller M, Tortola S, Toyota M, Capella G, Peinado MA, Baylin SB, Herman JG: Hypermethylation-associated inactivation of p14(ARF) is independent of p16(INK4a) methylation and p53 mutational status. Cancer Res 2000;60:129-133.

24 Xing EP, Nie Y, Song Y, Yang GY, Cai YC, Wang LD, Yang CS: Mechanisms of inactivation of p14ARF, p15INK4b, and p16INK4a genes in human esophageal squamous cell carcinoma. Clin Cancer Res 1999;5:27042713 .

25 Konishi N, Nakamura M, Kishi M, Nishimine $\mathrm{M}$, Ishida E, Shimada K: Heterogeneous methylation and deletion patterns of the INK4a/ARF locus within prostate carcinomas. Am J Pathol 2002;160:1207-1214.

-26 Svensson S, Nilsson K, Ringberg A, Landberg G: Invade or proliferate? Two contrasting events in malignant behavior governed by 16 (INK4a) and an intact Rb pathway illustrated by a model system of basal cell carcinoma. Cancer Res 2003;63:1737-1742.

27 Hanahan D, Weinberg RA: The hallmarks of cancer. Cell 2000;100:57-70.

28 Yaginuma Y, Hayashi H, Kawai K, Kurakane T, Saitoh Y, Kitamura S, Sengoku K, Ishikawa $\mathrm{M}$ : Analysis of the Rb gene and cyclin-dependent kinase 4 inhibitor genes (p16INK4 and p15INK4B) in human ovarian carcinoma cell lines. Exp Cell Res 1997;233:233239.

-29 Anwar F, Emond MJ, Schmidt RA, Hwang HC, Bronner MP: Retinoblastoma expression in thyroid neoplasms. Mod Pathol 2000; 13:562-569.

30 Holm R, Nesland JM: Retinoblastoma and p53 tumour suppressor gene protein expression in carcinomas of the thyroid gland. J Pathol 1994;172:267-272.

31 Okamoto A, Demetrick DJ, Spillare EA, Hagiwara K, Hussain SP, Bennett WP, Forrester K, Gerwin B, Serrano M, Beach DH, et al: Mutations and altered expression of p16INK4 in human cancer. Proc Natl Acad Sci USA 1994;91:11045-11049.

32 Kamijo T, Weber JD, Zambetti G, Zindy F, Roussel MF, Sherr CJ: Functional and physical interactions of the ARF tumor suppressor with p53 and Mdm2. Proc Natl Acad Sci USA 1998;95:8292-8297.

>33 Nickeleit I, Zender S, Kossatz U, Malek NP: p27kip1: a target for tumor therapies? Cell Div 2007;2:13.

>34 Bugni JM, Han J, Tsai MS, Hunter DJ, Samson LD: Genetic association and functional studies of major polymorphic variants of MGMT. DNA Repair (Amst) 2007;6:11161126.

35 Resnick MB, Schacter P, Finkelstein Y, Kellner Y, Cohen O: Immunohistochemical analysis of p27/kip1 expression in thyroid carcinoma. Mod Pathol 1998;11:735-739. 
\36 Karlidag T, Cobanoglu B, Keles E, Alpay HC, Ozercan I, Kaygusuz I, Yalcin S, Sakallioglu O: Expression of Bax, p53, and p27/kip in patients with papillary thyroid carcinoma with or without cervical nodal metastasis. Am J Otolaryngol 2007;28:31-36.

>37 Kang GH, Lee HJ, Hwang KS, Lee S, Kim JH, Kim JS: Aberrant CpG island hypermethylation of chronic gastritis, in relation to aging, gender, intestinal metaplasia, and chronic inflammation. Am J Pathol 2003;163:15511556.

-38 Sato F, Harpaz N, Shibata D, Xu Y, Yin J, Mori Y, Zou TT, Wang S, Desai K, Leytin A, Selaru FM, Abraham JM, Meltzer SJ: Hypermethylation of the p14(ARF) gene in ulcerative colitis-associated colorectal carcinogenesis. Cancer Res 2002;62:1148-1151.
39 Matsubayashi S, Kawai K, Matsumoto Y, Mukuta T, Morita T, Hirai K, Matsuzuka F, Kakudoh K, Kuma K, Tamai H: The correlation between papillary thyroid carcinoma and lymphocytic infiltration in the thyroid gland. J Clin Endocrinol Metab 1995;80: 3421-3424.

40 Kashima K, Yokoyama S, Noguchi S, Murakami N, Yamashita $H$, Watanabe $S$, Uchino S, Toda M, Sasaki A, Daa T, Nakayama I: Chronic thyroiditis as a favorable prognostic factor in papillary thyroid carcinoma. Thyroid 1998;8:197-202.

41 Gupta S, Patel A, Folstad A, Fenton C, Dinauer CA, Tuttle RM, Conran R, Francis GL: Infiltration of differentiated thyroid carcinoma by proliferating lymphocytes is associated with improved disease-free survival for children and young adults. J Clin Endocrinol Metab 2001;86:1346-1354.

42 Santoro M, Melillo RM, Fusco A: RET/PTC activation in papillary thyroid carcinoma: European Journal of Endocrinology Prize Lecture. Eur J Endocrinol 2006;155:645653.
3 Viglietto G, Chiappetta G, Martinez-Tello FJ, Fukunaga FH, Tallini G, Rigopoulou D, Visconti R, Mastro A, Santoro M, Fusco A: RET/PTC oncogene activation is an early event in thyroid carcinogenesis. Oncogene 1995;11:1207-1210

-44 Rebelo S, Domingues R, Catarino AL, Mendonca E, Santos JR, Sobrinho L, Bugalho MJ: Immunostaining and RT-PCR: different approaches to search for RET rearrangements in patients with papillary thyroid carcinoma. Int J Oncol 2003;23:1025-1032.

45 Xing M, Cohen Y, Mambo E, Tallini G, Udelsman R, Ladenson PW, Sidransky D: Early occurrence of RASSF1A hypermethylation and its mutual exclusion with BRAF mutation in thyroid tumorigenesis. Cancer Res 2004;64:1664-1668. 